\title{
Erratum to: Risk Factors for Weight Loss Among Patients Surviving 5 Years After Esophageal Cancer Surgery
}

Lena Martin, RD, $\mathbf{P h D}^{1,2}$ and Pernilla Lagergren, $\mathrm{RN}, \mathbf{P h D}^{2}$

${ }^{1}$ Department of Biosciences and Nutrition, Karolinska Institutet, Stockholm, Sweden; ${ }^{2}$ Department of Molecular Medicine and Surgery, Karolinska Institutet, Stockholm, Sweden

ERRATUM TO: ANN SURG ONCOL

(2015) 22:610-616

DOI 10.1245/S10434-014-3973-2

In the initial online publication, the authors' family names and given names were interchanged. The names have been corrected in the publication as shown in this erratum.

The online version of the original article can be found under doi:10.1245/s10434-014-3973-2.

(C) Society of Surgical Oncology 2015

Published Online: 5 February 2015

L. Martin, RD, $\mathrm{PhD}$

e-mail: lena.martin@karolinska.se 